\title{
Assessing Campus Sustainability: A Report from Diponegoro University, Indonesia
}

\author{
M. Mujiya Ulkhaq, Putra Indra Prayogo, Miftah Firmansyah, and Debora Agustina
}

\begin{abstract}
There exist explicit pressures to the universities to integrate sustainability into their systems due to numerous declarations and commitments related to the need of sustainability in higher education. As a consequence, there are several frameworks for achieving campus sustainability. The objective of this research is to verify the adherence between the condition at Diponegoro University and the framework for achieving campus sustainability proposed by Alshuwaikat and Abubakar. A case study is conducted through observation, data and document collection, and interview with the university's stakeholders, professors, lecturers, and students of the university. It can be concluded that the university is partially adherence with the framework at the time this research was performed. Several recommendations are proposed to the university to be more sustainable.
\end{abstract}

Index Terms - Assessment, sustainability, universities.

\section{INTRODUCTION}

There has been a rising of international attention in the role of higher education in promoting sustainability since the Stockholm Declaration on the Human Environment in 1972, which has been recognized as the first reference about sustainability in higher education. In Recommendation 96, it is recommended to establish an international program in environmental education [1]. Three years later, this recommendation was addresses at the International Environmental Workshop in Belgrade, Serbia (in the former Yugoslavia). It is proposed a global framework for environmental education, referred as the Belgrade Charter [2] In 1977, UNESCO held the Intergovernmental Conference on Environmental Education in Tbilisi, Georgia (in the former USSR). The Tbilisi Report is built upon the Belgrade Charter and promoted environmental teaching, research, training, and technical and vocational education. It produced twelve guiding principles of environmental education programs, adjusted the eight guiding principles of Belgrade Charter [3].

The first official statement made by university of a commitment to environmental sustainability in higher education was taken place in Talloires, France, in 1990. The Talloires Declaration is a ten-point action plan for incorporating sustainability and environmental literacy in

Manuscript received October 20, 2014; revised February 28, 2015

M. Mujiya Ulkhaq is with Industrial and Management System Engineering, Kyung Hee University, Rep. of Korea. He is also with Industrial Engineering Department, Diponegoro University, Semarang, Indonesia (e-mail: mujiya.ulkhaq@gmail.com)

I. P. Prayogo, M. Firmansyah, and D. Agustina are with Industrial Engineering Department, Diponegoro University, Semarang, Indonesia (e-mail: putraip13@gmail.com, miftahfirmansyah@gmail.com, debby.deboraagustina@gmail.com). teaching, research, operations, and outreach at colleges and universities. It has been signed by over 350 university presidents and chancellors in over 40 countries [4]. Over the period 8-11 December 1991 the presidents and senior representatives of 33 universities met in Halifax, Canada, to take stock of the role of universities regarding the environment and development. The Halifax Declaration expressed a disappointment about the continuing widespread degradation of the earth's environment and the pervasive influence of poverty on the process [5].

The term education for sustainable development emerged on the Earth Summit in Rio de Janeiro in 1992. For many educators, it is defined more broadly than environ- mental education to include issues of international develop- ment, cultural diversity, and social and environmental equity [6]. This Earth Summit produced the well-known "Agenda 21". Chapter 36 makes brief but specific reference to universities and colleges and their role in building a sustainable future [7]. Since then, there are numerous events, conferences, and declarations related to the role of higher education in fostering a sustainable future, from Swansea Declaration until Lucerne Declaration [8]-[19] (see Table I for the complete list).

As a consequence of those aforementioned declarations, signed commitments, and voluntary decisions, universities should integrate sustainability into their systems. In addition, many articles emphasized the need for sustainability in higher education [20], [21]. However, to some universities, sustainability is just a matter of master plan, environmental plan, or environmental statements [22]. Some universities consider those declarations as a challenge to establish a sustainable campus [23]. Others create individual institutional policies or utilize framework and tools to attain campus sustainability, such as ISO 14001 [24]-[26], eco-management and audit scheme (EMAS) [27], green building initiative [28], environmental impact assessment [29], graphical assessment of sustainability in universities (GASU) [30], [31], sustainability tracking, assessment and rating system (STARS) [32]-[34], and Alshuwaikat and Abubakar's framework [35], [36] to attain campus sustainability.

This research adopted the last framework since it allows all sustainability issue in a systematic and integrated way [35]. The framework also could manage the limitations of some other frameworks follows. ISO 14001 has been criticized of its lack of economic and social dimension [30], [37]. Although the EMAS is considered has stronger requirements concerning quantification of environmental targets and publication of an environmental declaration compared to ISO 14001 , but the rate of implementation appears to be decreasing among corporates and institutions [35]. The green building initiative, on the other hand, cannot alone guarantee sustainability as it lacks a systematic and continuous campus 
quality improvement [35]. The other framework, STARS, is more useful for higher education institutions in developed countries. The survey conducted in Malaysia indicates that some variables are not completely appropriate to the Malaysian context [38].

TABLE I: DECLARATIONS ON HIGHER EDUCATION AND SUSTAINABLE DEVELOPMENT

\begin{tabular}{|c|c|c|}
\hline Year & Location (city, country) & Declaration \\
\hline 1972 & Stockholm, Sweden & Stockholm Declaration, United Nations Conference on the Human Environment \\
\hline 1975 & Belgrade, Serbia (former Yugoslavia) & The Belgrade Charter, International Workshop on Environmental Education \\
\hline 1977 & Tbilisi, Georgia (former USSR) & Tbilisi Declaration, Intergovernmental Conference on Environmental Education \\
\hline 1990 & Talloires, France & Talloires Declarations, Presidents Conference \\
\hline 1991 & Halifax, Canada & Halifax Declaration, Conference on University Action for Sustainable Development \\
\hline 1992 & Rio de Janerio, Brazil & $\begin{array}{l}\text { Agenda } 21 \text { - Chapter 36: Promoting Education, Public Awareness and Training, United Nations } \\
\text { Conference on Environment \& Development }\end{array}$ \\
\hline 1993 & Swansea, United Kingdom & $\begin{array}{l}\text { Swansea Declaration, Association of Commonwealth Universities' Fifteenth Quinquennial } \\
\text { Conference }\end{array}$ \\
\hline 1993 & Kyoto, Japan & Kyoto Declaration, International Association of Universities Ninth Round Table \\
\hline 1994 & Geneva, Switzerland & The Copernicus Charter, Conference of European Rectors \\
\hline 1997 & Thessaloniki, Greece & $\begin{array}{l}\text { Thessaloniki Declaration, International Conference on Environment and Society: Education and } \\
\text { Public Awareness for Sustainability }\end{array}$ \\
\hline 1998 & Paris, France & $\begin{array}{l}\text { World Declaration on Higher Education for the Twenty-first Century: Vision and Action, and } \\
\text { Framework for Priority Action for Change and Development in Higher Education, World } \\
\text { Conference on Higher Education }\end{array}$ \\
\hline 2001 & Lüneburg, Germany & The Lüneburg Declaration on Higher Education for Sustainable Development \\
\hline 2004 & Barcelona, Spain & $\begin{array}{l}\text { Declaration of Barcelona, Education in Sustainable Development (EESD) } 2004 \text { Conference } \\
\text { Scientific Committee }\end{array}$ \\
\hline 2005 & Graz, Austria & Graz Declaration on Committing Universities to Sustainable Development \\
\hline 2006 & Strasbourg, France & $\begin{array}{l}\text { Declaration on the Responsibility of Higher Education for a Democratic Culture - Citizenship, } \\
\text { Human Rights and Sustainability }\end{array}$ \\
\hline 2007 & Lucerne, Switzerland & Lucerne Declaration on Geographical Education for Sustainable Development \\
\hline 2009 & Tokyo, Japan & Tokyo Declaration of Hope, Asia-Pacific Forum for ESD Educators and Facilitators \\
\hline
\end{tabular}

The framework is proposed by researchers from emerging countries and the adoption of this framework is well accepted in India [36] as a part of emerging countries. Object of the research is Diponegoro University, which is located in Indonesia. Since the research is conducted in emerging country universities, it is expected that the framework will be beneficial as a study to achieve campus sustainability, due to only a few studies related to campus sustainability in Indonesia.

The adherence between the framework and what have been done by the object of the research to achieve sustainability follows the classification by [36]:

1) Inexistent adherence, when the university does not adopt any of the practices recommended in the framework;

2) Partial adherence, when the university adopted a few of the practices recommended in the framework;

3) Full adherence, when the university adopted all of the practices recommended in the framework.

This paper is organized as follows. In Section II, the framework that is used in this research is analyzed. In Section III, the methodology used in this research is presented. The result of the research is offered in Section IV. Finally, final remark and future research direction are presented in the last section.

\section{FRAMEWORK}

The framework that is used in this research is proposed by Alshuwaikat and Abubakar [35]. To achieve campus sustainability, they recommended adopting three pillars, namely: university environmental management systems (EMS); public transportation and social responsibility; and sustainability teaching and research in an integrated way.

University EMS constitutes the set of overall procedures, practices, processes, and resources to develop, implement, achieve, review, and maintain the policy of attaining sustainable environment. It consists of two strategies: environmental management and improvement, and green campus. The first could be performed by promoting: minimizing negative impacts of campus operations, pollution prevention, energy efficiency, resource conservation, environmental improvement, waste reduction, recycling, etc. The second strategy can be carried out through green building, green transportation, and campus preservation.

Public participation and social responsibility deals with the participation of university stakeholders in achieving sustainability. It composes of three strategies, namely public participation, community services, and social justice. Public participation could be done through campus community, alumni, and partnership. Community services through public lectures and awareness, and community projects, while social justice through equity and care for handicapped people.

The last pillar, sustainability teaching and research, is related with conferences, seminars, and workshops lead by university in fostering the sustainability. University also has to provide courses and curriculum related to sustainability, health and safety, and livable settlements. Research and development associated with renewable energy, environmental protection, and climate change also could support the university's effort to attain sustainability.

\section{METHODOLOGY}

The research has been conducted at Diponegoro University, 
which is located in Semarang, Central Java Province, Indonesia. It belongs to top-ten best universities in Indonesia and considered as one of the popular university in Indonesia.
Every year, almost 11,000 of new students are accepted, comprise from diploma, undergraduate, master, and doctoral programs.

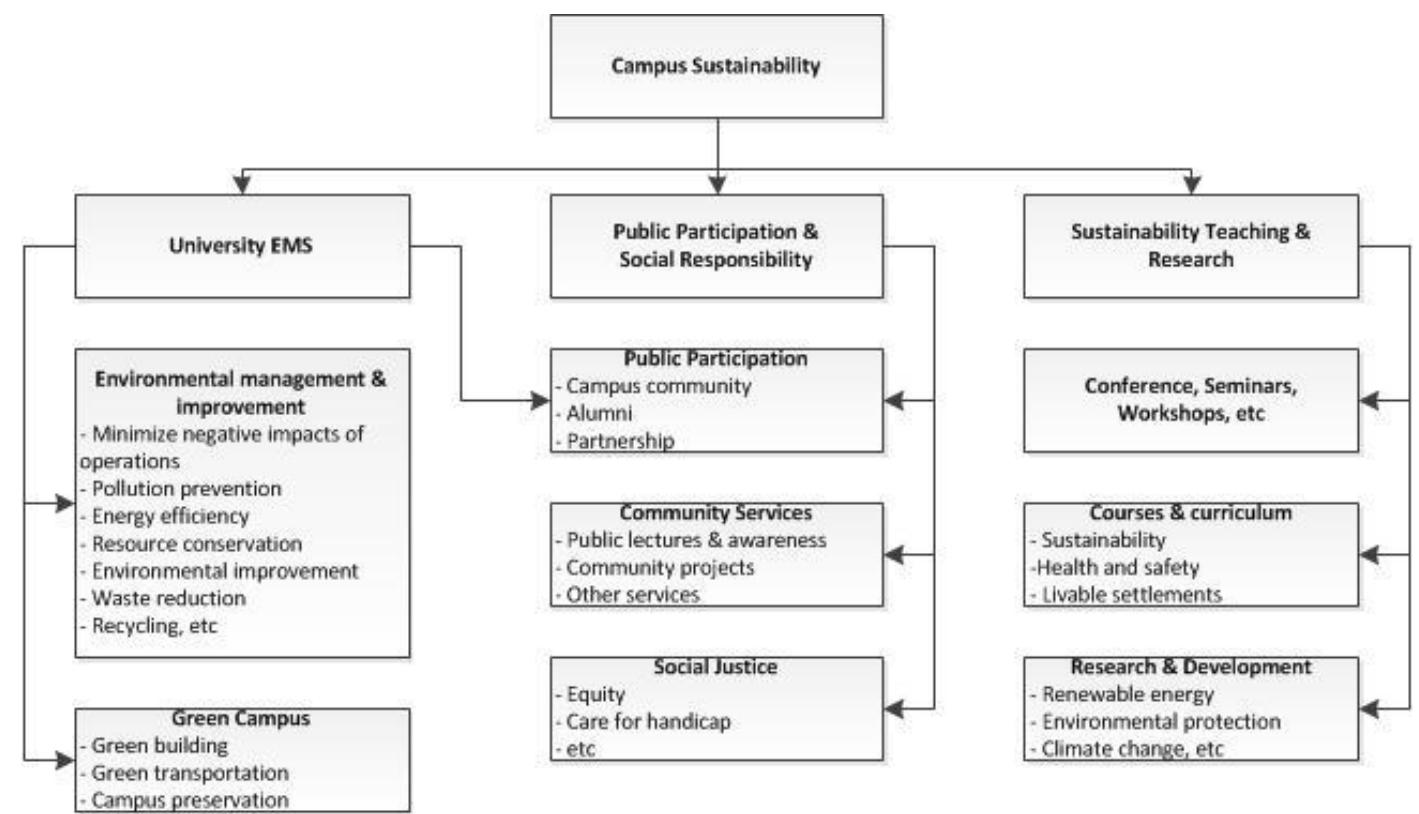

Fig. 1. Framework for assessing campus sustainability. Source: [35].

This research is a qualitative study based on case study methods [39]. It is used observation, data and document collecting, and interview as research instruments. The observation is conducted to be aware of the reality in the university. Data and document collection has been done by compiling the information through university website and other documents related to the implementation of sustainability practices in the university. We did interviews with the university's stakeholders, professors, lecturers, and students of the university.

The data which have been collected is analyzed to verify the adherence of the framework in Fig. 1 to the reality at Diponegoro University. The information is then classified into several categories according to the framework. It is analyzed in the aggregate, hence trying to make a conclusion about the condition at the university according to the framework, i.e. formally implemented, exist informally, and no evidence. In the end, the inference is made, whether there is inexistent, partially, or fully adherence between the framework and the reality at the university.

\section{RESULT}

\section{A. University EMS}

Garbage separation as a part of waste management has been done by Diponegoro University. Organic and inorganic trashes are separated into different trash bin which is placed in various corner of the university. Garbage separation makes it possible to make compost with organic waste. It also can facilitate the reuse of inorganic trashes, like bottles, cans, and metals, thereby reducing the waste that ends up in landfills. These inorganic wastes are then could be recycled into several items, such as bottle, lumber, garbage cans, rope, scrapers, etc. The university has waste treatment facilities managed by environmental engineering and chemical engineering department.

The university has several programs related to the pollution prevention. Green transportation is one of main program for pollution prevention. The university promotes the use of bicycle through program Friday planting, cycling, and breakfasting. This program is regularly held every week. It starts with cycling around the university with university's professors and lectures, and ends up with breakfasting together. Not only university students, but also citizen around university could participate in this program. To succeeded this program, the university provides bicycles, bicycle shelters, and bicycle path. Another program is car free day which is frequently organized every Friday once a month by closing all the roads go through the university. Moreover, every year, about 8,000 trees are planted in numerous points which are intended to be green area. The university involved new students to participate in this program.

Several bio-pores, a narrow hole bored into the ground (about $10 \mathrm{~cm}$ across and $100 \mathrm{~cm}$ in deep) which is filled with organic matters, has been made in strategic locations within the university. These bio-pores could encourage root and worm activities, to increase the porosity of the soil. Increasing the ability of the soil to absorb water is a big issue in Indonesia, where flooding is a big problem. Groundwater recharges, as a translation of sumur resapan, also have been created in several points to intercept and retain water from rain and infiltrate it into the ground. This is a like a much wider bio-pore which holds water while it drains slowly into the ground.

Paperless promotion as a program to minimize waste also has been done by the university. It is carried out the applying online system. In addition, students from environmental engineering have a program of creating fertilizer from the leaves which are fallen from the trees. 
TABLE II: ADHERENCE TO THE FRAMEWORK

\begin{tabular}{|l|c|c|c|}
\hline Strategies & Formally Implemented & Exist Informally & No Evidence \\
\hline University EMS: & & & \\
\hline Minimize negative impacts of operations & & V & \\
\hline Pollution prevention & V & V & \\
\hline Energy efficiency & & V & \\
\hline Resource conservation & & V & \\
\hline Environmental improvement & V & & \\
\hline Waste reduction & & V & \\
\hline Recycling & & & \\
\hline Green building & V & & \\
\hline Green transportation & V & & \\
\hline Campus preservation & & & \\
\hline Public Participation and Social Responsibility: & V & & \\
\hline Campus community & V & & \\
\hline Alumni & V & & \\
\hline Partnership & V & & \\
\hline Public lectures \& awareness & V & & \\
\hline Community projects & V & & \\
\hline Other services & V & & \\
\hline Equity & & & \\
\hline Care for handicap & & & \\
\hline Sustainability teaching and research: & & & \\
\hline Conferences, Seminars, Workshop & & & \\
\hline Sustainability & & & \\
\hline Health and safety & & & \\
\hline Livable settlements & & & \\
\hline Renewable energy & & & \\
\hline Environment protection & & & \\
\hline
\end{tabular}

Some of the buildings have been designed with the concept of energy efficient, such as the building of environmental engineering department. The rooms are well-designed so that one room could be partitioned into some rooms. Central air conditioner and central lighting are used in this "big rooms", hence there is one air conditioner and one lighting for more than one rooms (partitioned rooms) rather than one air conditioner and one lighting for one room. This could minimize the utilization of the energy.

The university has a "deer park" that is built to preserve the deer in Indonesia. In front of deer park, there is an open space for preserving endangered plants. Forest campus is a new program which is still in the development stage. Those all programs make Diponegoro University top 47 in green campus world rankings and top 3 in Indonesia.

\section{B. Public Participation and Social Responsibility}

There are several communities in the university that are engaged with environmental issues. Some of them are "Oxygen 16," "Environmental Study Group," "Kesemat," "Atmosphere," and "Diponegoro Social Care." They have several programs such as campus cleaning and composting by Oxygen 16; training for creating bio-pore and tarakura home method composting by Environmental Study Group; mangrove conservation in Semarang coastal area by Kesemat, green competition, youth dialog, and youth in action by Atmosphere; and garbage bank and plastic and paper campaign by Diponegoro Social Care.

Alumni of the university have vital role in fostering campus sustainability. They donated to the university in the form of trees for trees planting program and also donation for bio-pore program.

Diponegoro University recently has established a partnership with the French government related to conservation of mangrove forest. Another partnership also has been created with the government, such as Ministry of Environment and Ministry of Forestry. The first is a preservation program of Rawa Pening, name of a swamp located near Semarang, and the last is trees planting program.

The university complies with social justice principles, giving the opportunity for education to everyone, regardless of gender, religion, favorable economic conditions, etc. In addition, the university offers some scholarship for students, such as BUMN scholarship, PPA scholarship, BBM scholarship, and Supersemar scholarship.

\section{Sustainability Teaching and Research}

Diponegoro University has conducted conference related to environmental issues, such as "International Conference on Tropical and Coastal Eco-Development 2014," Several national seminars also have been offered, such as "National Seminar of Management of Natural Resources and Environment 2013" and "National Seminar of Management Environment."

Several courses related to environment are applied in some departments besides environment-related department, for example in industrial engineering department which is applied ecological industry class, design for sustainability class, and green supply chain management class. Urban and regional planning department also applied such classes, such as urban sustainability class.

Research about renewable energy, environmental protection, and also climate change have been started and still in the stage of development and improvement. Geothermal building has been built in the management of Faculty of Science and Mathematics. 


\section{Adherence to the Framework}

Table II shows systematically the adherence between framework and the condition at Diponegoro University. In general, the university has been developed most of sustainability strategies suggested in the framework. Twelve strategies are finally implemented; nine strategies are informally implemented; while the rests are no evidence. The absences of some strategies, is recommended:

1) Establish a program for recycling some can-be-recycled products;

2) Promote a program for the handicap and students of special needs;

3) Develop a research for renewable energy sources, such as wind, solar energy, and other renewable form that could provide the long-term key to reduce emissions.

In summary, we may indicate that Diponegoro University at the time this research was performed, had a partially adherence level with respect to the strategies suggested in the framework.

\section{FinAl REMARK AND Future RESEARCH DiRECTION}

The framework proposed by Alshuwaikat and Abubakar [35] is a valuable instrument to assess the campus sustainability. Quantification of this framework to evaluate whether such university is categorized as sustainable or not is very recommended. It also recommends conducting similar research in the developing countries and compares it with the research conducted in the emerging countries. It is also suggested to assess the adherence between the condition in the university and the other frameworks such as GASU [30], STARS, and Campus Sustainability Assessment Framework [38], both in emerging countries and developing countries.

\section{ACKNOWLEDGMENT}

Authors would like to thank to the Vice Rector of Student Affairs for his support in this research.

\section{REFERENCES}

[1] United Nations, Report of the United Nations Conference on the Human Environment, 1973.

[2] UNESCO, The Belgrade Charter: A Framework for Environmental Education, 1975.

[3] UNESCO, Intergovernmental Conference on Environmental Education, 1977.

[4] (1990). Association of university leaders for a sustainable future. Talloires Declaration. [Online]. Available: http://www.ulsf.org/pdf/TD.pdf.

[5] (1991). International association of universities, UN University, and association of universities and Colleges of Canada. Halifax Declaration. [Online]. Available: http://www.iisd.org/educate/declarat/halifax.htm

[6] W. Calder and R. M. Clugston, "International efforts to promote higher education for sustainable development," Planning for Higher Education, vol. 31, no. 3, pp. 30-44, 2003.

[7] United Nations, Agenda 21, 1992.

[8] (1993). Association of commonwealth universities. Swansea Declaration. [Online]. Available: http://www.iisd.org/educate/declarat/swansea.htm

[9] (1993). International Association of Universities Ninth Round Table. Kyoto Declaration, [Online]. Available: http://www.iisd.org/educate/declarat/kyoto.htm

[10] (1993). Association of European Universities. Copernicus: The University Charter for Sustainable Development. [Online]. Available: http://www.iisd.org/educate/declarat/coper.htm

[11] UNESCO, Thessaloniki Declaration, 1997.
[12] D. Knapp, "The Thessaloniki Declaration: A wake-up call for environmental education?" The Journal of Environmental Education, vol. 31, no. 3, pp. 32-39, 2000 .

[13] UNESCO, World Declaration on Higher Education for the Twenty-first Century: Vision and Action, and Framework for Priority Action for Change and Development in Higher Education, 1998.

[14] UNESCO, The Lüneburg Declaration on Higher Education for Sustainable Development, 2001.

[15] (2004). Engineering Education for Sustainable Development Observatory. Declaration of Barcelona. [Online]. Available: https://www.upc.edu/eesd-observatory/who/declaration-of-barcelona

[16] (2005). Copernicus-Campus, the Karl-Franzens-University Graz, the Technical University Graz, Oikos International. Graz Declaration on Committing Universities to Sustainable Development. [Online] Available: http://www.uni-graz.at/sustainability/Graz_Declaration.pdf

[17] (2006). Council of Europe Global Network for Higher Education and Democratic Culture. Declaration on the Responsibility of Higher Education for a Democratic Culture - Citizenship, Human Rights and Sustainability. [Online]. Available: http://www.ehea.info/Uploads/Declaration_EN.pdf

[18] S. Reinfried, Y. Schleicher, and A. Rempfler, "Geographical views on education for sustainable development," in Proc. the Lucerne-Symposium, Switzerland, 2007, pp. 29-31.

[19] Asia-Pacific Forum for ESD Educators and Facilitators, Tokyo Declaration of Hope, 2009.

[20] P. Viebahn, "An environmental management model for universities: From environmental guidelines to staff involvement," Journal of Cleaner Production, vol. 10, no. 1, pp. 3-12, 2002.

[21] P. Barnes and P. Jerman, "Developing an environmental management system for a multiple-university consortium," Journal of Cleaner Production, vol. 10, no. 1, pp. 33-39, 2002.

[22] L. Velazquez, N. Munguia, A. Platt, and J. Taddei, "Sustainable university: What can be the matter?" Journal of Cleaner Production, vol. 14 , no. 9, pp. 810-819, 2006.

[23] T. S. A. Wright, "Definitions and frameworks for environmental sustainability in higher education," International Journal of Sustainability in Higher Education, vol. 3, no. 33, pp. 203-220, 2002

[24] R. M. Fisher, "Applying ISO 14001 as a business tool for campus sustainability: A case study from New Zealand," International Journal of Sustainability in Higher Education, vol. 4, no. 2, pp. 138-150, 2003.

[25] T. J. Price, "Preaching what we practice: Experiences from implementing ISO 14001 at the University of Glamorgan," International Journal of Sustainability in Higher Education, vol. 6, no. 2, pp. 161-178, 2005.

[26] K. Sammalisto and T. Brorson, "Training and communication in the implementation of environmental management systems (ISO 14001): A case study at the University of Gävle, Sweden," Journal of Cleaner Production, vol. 16, no. 3, pp. 299-309, 2008.

[27] B. Delakowitz and A. Hoffmann, "The Hochschule Zittau/Görlitz: Germany's first registered environmental management (EMAS) at an institution of higher education," International Journal of Sustainability in Higher Education, vol. 1, no. 1, pp. 35-47, 2000.

[28] K. A. Owens and A. Halfacre-Hitchcock, "As green as we think? The case of the College of Charleston green building initiative," International Journal of Sustainability in Higher Education, vol. 7, no. 2, pp. 114-128, 2006.

[29] T. B. Ramosa, T. Cecílio, and J. J. de Melo, "Environmental impact assessment in higher education and training in Portugal," Journal of Cleaner Production, vol. 16, no. 5, pp. 639-645, 2008.

[30] R. Lozano, "A tool for a Graphical Assessment of Sustainability in Universities (GASU)," Journal of Cleaner Production, vol. 14, no. 9 , pp. 963-972, 2006.

[31] R. Lozano, "The state of sustainability reporting in universities," International Journal of Sustainability in Higher Education, vol. 12, no. 1, pp. 67-78, 2011

[32] K. C. Murphy, "Evaluating the sustainability tracking, assessment and rating system (STARS) at the Evergreen State College," M.S. thesis Dept. Physics and Sustainable Design, The Evergreen State College, Olympia, WA, 2009.

[33] A. Wigmore and M. Ruiz, "Sustainability assessment in higher education institutions. The stars system," Ramon Llull Journal of Applied Ethics, vol. 1, no. 1, pp. 25-42, 2010.

[34] M. Urbanski and W. L. Filho, "Measuring sustainability at universities by means of the sustainability tracking, assessment and rating system (STARS): Early findings from STARS data," Environment, Development and Sustainability, pp. 1-12, 2014.

[35] H. M. Alshuwaikat and I. Abubakar, "An integrated approach to achieving campus sustainability: Assessment of the current campus 
environmental management practices," Journal of Cleaner Production, vol. 16, no. 16, pp. 1777-1785, 2008.

[36] R. de Castro and C. J. C. Jabbour, "Evaluating sustainability of an Indian University," Journal of Cleaner Production, vol. 61, pp. 54-58, 2013.

[37] U. Steger, "Environmental management systems: empirical evidence and further perspectives," European Management Journal, vo. 18, no.1, pp. 23-37, 2000.

[38] O. Saadatian, K. B. Sopian, and E. Salleh, "Adaptation of sustainability community indicators for Malaysian campuses as small cities," Sustainable Cities and Society, vol. 6, pp. 40-50, 2013.

[39] R. K. Yin, Case Study Research: Design and Methods (Applied Social Research Methods), 5th ed., Sage Publication, Inc.: London, 2013.

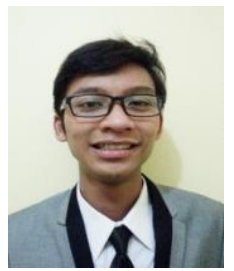

M. Mujiya Ulkhaq received his bachelor degree in Industrial Engineering Department from Diponegoro University, Semarang, Indonesia. He is currently a graduate student of Industrial and Management Systems Engineering Department of Kyung Hee University, Rep. of Korea.

$\mathrm{He}$ is a lecturer in Industrial Engineering Department of Diponegoro University. He teaches design for sustainability. He has presented several presentations in several international conferences.

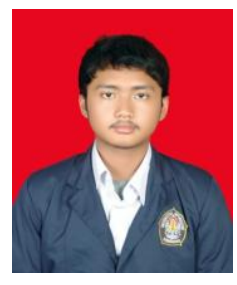

Putra Indra Prayogo was born in Indonesia on September 13, 1992. He is an undergraduate student in Diponegoro University, Semarang, Indonesia, majoring in industrial engineering. He is a member of Industrial Engineering Student's Association.

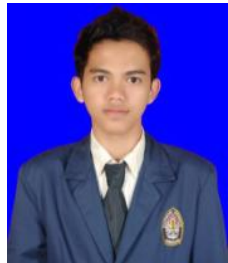

Miftah Firmansyah was born in Indonesia on August $11,1993 . \mathrm{He}$ is an undergraduate student in Diponegoro University, Semarang, Indonesia, majoring in industrial engineering. He is a leader of Industrial Engineering Student's Association.

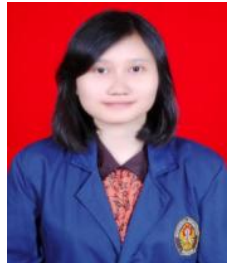

Debora Agustina was born in Indonesia on August 3 , 1994. She is an undergraduate student in Diponegoro University, Semarang, Indonesia, majoring in industrial engineering. She is a member of Industrial Engineering Student's Association. 